\title{
Llumuna
}

Vol. 21, No. 2, 2017, p. 345-369

Journal of Islamic Studies Published by State Islamic University Mataram

p-ISSN 1411-3457, e-ISSN 2355-7648, available online at http://ulumuna.or.id

\section{THE DEVELOPMENT OF HADITH STUDY CONTROVERSY IN INDONESIA: A STUDY OF MIȘBĀḤ AL-ẒULĀM BY MUHAJIRIN AMSAR AL-DARI}

\section{Fatihunnada}

Fakultas Dirasat Islamiyah, UIN Syarif Hidayatullah Jakarta e-mail: fatihunnada@uinjkt.ac.id

\begin{abstract}
There has been a wide presumption that hadith literature authored by Indonesian Muslim scholars is simple and static. This article challenges this view. It examines Miṣbāh al-Zulām, a commentary of Bulūg al-Marām, by Muhajirin Amsar al-Dari to show the dynamic development of the study on ikhtiläfal-hadith (disputes over hadith). Grounded in the hermeneutic approach, this article argues that the development of hadith studies in Indonesia from time to time is not as simple as the general presupposition entails. This article shows that the development of hadith studies is raised following the provision of studies on ikhtiläf al-hadith. The tradition of $w$ riting hadith in Indonesia began in the $17^{\text {th }}$ century and, as a result, a number of hadith literatures have been produced by Indonesian Muslim scholars. This development challenges some scholars' perception that the studies of hadith in Indonesia remain simple and the science of hadith in the country is hardly available.
\end{abstract}

Keywords: Development of hadith, contradiction of hadith, Muhajirin Amsir, Miṣbāh al-Zulām, Indonesia

DOI: http://dx.doi.org/10.20414/ujis.v21i2.276

\section{Introduction}

SCHOLARS SUGGEST that the study of hadith in Indonesia does not thrive well. This can be seen from the fact that the books and literature used in Islamic boarding school are only the books of Islamic law (figh), language, theology (ushuluddin), Sufism, and 
interpretation (tafsir). ${ }^{1}$ Meanwhile, the book of Ṣaḥih al-Bukhārī is only made as a reference by Muslim clerics. ${ }^{2}$ Thus, it implies that the expertise of Indonesian Muslim scholars in the field of hadith is inadequate. Such a phenomenon has led scholar to doubt the involvement and contribution of Indonesian Muslim scholars in the field of hadith. ${ }^{3}$ To respond to such doubt, it is necessary to present a comprehensive study that explores hadith literature authored by Muslim scholars emerging from the country. Therefore, such existing work needs studying critically, including those from the early period. ${ }^{4}$ Indonesian Muslim clerics have actually published a myriad of studies pertinent to hadith, ${ }^{5}$ which demonstrates their mastery in the sphere of hadith and scientific of hadith. ${ }^{6}$

The current study aims to delineate the development of studies on hadith in Indonesia throughout the $20^{\text {th }}$ century. ${ }^{7}$ In

${ }^{1}$ Van den Berg in Karel A. Steenbrink, "Beberapa Aspek Tentang Islam di Indonesia Abad 19," in Beberapa Aspek tentang Islam di Indonesia Abad 19 (Jakarta: Bulan Bintang, 1984), 155-157.

2 Martin van Bruinessen, Kitab Kuning Pesantren dan Tarekat, Tradisi-Tradisi Islam di Indonesia (Bandung: Mizan, 1999), 29.

${ }^{3}$ Martin van Bruinessen, "A Note on Source Materials for The Biographies of Southeast Asian Ulama," La Transmission du Savoir Dans le Monde Musulman Peripherique, Lettre d'information 17 (1997): 57-66.

${ }^{4}$ In an article written by Abd. Moqsith Ghazali that describes about the marginalized position of non-Arabian scholars, and that their works are considered invalid, because non-Arabians are regarded as 'ajam (stranger) and not able to understand Islamic lessons in depth. See Abdul Moqsith Ghazali, "Ulama Arab dan Ulama Indonesia," Islamlib, last modified Oktober 2008, accessed February 11, 2016, http://islamlib.com/gagasan/isla mnusantara/ulama arab-dan-ulama-indonesia/.

${ }^{5}$ A complete statement can be seen in the notes by Abdur-Rahman M.A. et al. that explain the works of Muslim clericsfrom Southaeast Asia, exactly from Malay Peninsula, and among those works, ones which written by Indonesian Muslim clerics are quite dominat. See M.A. Abdur-Rahman et al., "Historical Review of Classical Ha dith Literature in Malay Peninsula," International Journal of Basic and Applied Sciences 11, no. 2 (2011).

${ }^{6}$ See Fauzi bin Deraman and Mohd Asmawibin Muhammad, "Karya-Karya 'Ulum al-Hadith di Nusantara: Satu Sorotan," Al-Bayan Journal of Qur'an and Hadith Studies 8 (2013): 14.

${ }^{7}$ Brown shows that al-Daruqutni was one of the critical hadith in sahihayn. This means that controversy over the hadith is not novel in the tradition of Islam. See Jonathan A. C. Brown, "Criticism of the Proto-Hadith Canon: Al-Daraqutni's 
particular, this research describes the origins of early history of mukhtaläf al-hadìth study development in Indonesia and the background of its emergence. For this reason, this study measures to what extent the study of hadith has so far been appealing in Indonesia. It aslo analyzes the methodology used to understand mukhtaläf al-hadith in Indonesia throughout the $20^{\text {th }}$ century regarding the measurement of Indonesian Muslim scholars in addressing the study of hadith and the disputes surrounding it.

This present study is a continuation of the previous studies on this topic and related issues. Jawiah Dakir and Ahmad Levi Fachrul Avivy ${ }^{8}$ explain that the Muslim scholars in Nusantara have their special excellence and style in understanding hadith. However, this study only gives an introduction about the figure of Muhajirin Amsar and a little review of the methodology of hadith commentary of Miṣbāh al-Zulām. Oman Fathurrahman ${ }^{9}$ traced again the roots of writing tradition of hadith works in Nusantara by focusing on the study of Hidāyat al-Habì and some other hadith works. Muhammad Mustaqim Mohd Zarif in 'Jawah Hadis Scholarship in the Nineteenth Century: A Comparative Study of the Adaptions of Lubāb al-Hadith composed by Nawawi of Banten (d. 1314/1897) and Wan 'Ali of Kelantan (d. 1331/1913) (2007) ${ }^{10}$ researched the similarities and differences between both said works in the method and approach to understand hadith and the language used.

Adjustment of the Sahihayn," Journal of Islamic Studies 15, no. 1 (January 1, 2004): $1-37$.

8 See Jawiah Dakir and Ahmad Levi Fachrul Avivy, "Ketokohan Sheikh Muhammad Muhajirin Amsar Al-Dary Sebagai Ilmuan Hadis Nusantara: Analisis Terhadap Kitab Miṣbāḥ Al-Ẓulām Sharḥ Bulūg Al-Marām," in Prosiding Nadwah Ulama Nusantara (NUN) IV (Bangi, Selangar: University Kebangsaan Malaysia, 2011),

231-236, http://www.ukm.my/nun/prosiding\%20atas\%20talian.htm.

${ }^{9}$ Oman Fathurrahman, "The Roots of the Writing Tra dition of Ha dìth Works in Nusantara: Hidāyat Al-Ḥabīb by Nūr Al-Dīn Al-Rānīrī," Studi Islamika Indonesian Journal for Islamic Studies 19, no. 1 (2012): 47-76.

10 Muhammad Mustaqim Mohd. Zarif, "Jawah Hadis Scholarship in the Nineteenth Century: A Comparative Study of the Adaptions of Lubāb Al-Hadith Composed by Nawawi of Banten (d. 1314/1897) and Wan 'Ali of Kelantan (d. 1331/1913)" (Dissertation, University of Edinburgh, 2007). 
Syuhudi Ismail explains that each Muslim scholar has different methods of solving the disputes (ikhtiläf) over hadith. A Muslim scholar may use one method, while others adopt more than one method. However, it does not mean that the result of their study must be different one another. Although they use different methods, the final result in solving such ikhtiläf may sometimes show many similarities. ${ }^{11}$

In solving the contradiction or disputes (ikhtila $\mathrm{f}$ ) of hadith, the majority of hadith experts have set out four theories in hierarchical order, not as an option: First, the method of al-jam' wa al-tawfi $q$; second, al-naskh; third, al-tarji h; and fourth, tawaqquf. However, in the theory of Shafi'i, there is no principle of al-tawaqquf, 12 which is what another Muslim scholar does as the last alternative regarding a conflicting proposition that cannot be compromised and resolved with the method of al-naskh or al-tarjīh. The explanation of those four steps can be seen as follow:

In addressing the contradiction or Mukhtalaf al-Hadith, the first step that is usually taken by the Muslim scholars is by applying the method of al-Jam' wa al-Tawfì (compromise). It means that mukhtalaf hadith can be solved by discovering the points of convergence in each content of meaning. Thus, the essential meaning addressed by those hadith can be revealed. ${ }^{13}$ The second method is al-naskh (abrogation), which is understood as a fact that some mukhtalaf al-hadith has provision content with similar topic, but it brings opposite meaning and it cannot be compromised. ${ }^{14}$

Another method is al-tarjīh, formulated by the Muslim scholars and defined as "the method of comparing the propositions that are seemingly contradictory in order to know which has a strong argument or position than the other one". Yet, only a few Muslim scholars state that tarjih on mukhtalaf hadith can

11 M. Syuhudi Ismail, Hadis Nabi Menurut Pembela, Pengingkar, dan Pemalsunya (Jakarta: Bulan Bintang, 1995), 111-113.

12 Muhammad ibn Idrīs Al-Shāfi'î, Al-Risālat (Cairo: Maktabat al-Ḥalabi, 1940), 216.

13 Nafiz Husayn Ḥammād, Mukhtalaf al-Hadìth Bayn al-Fuqahā' wa alMuhaddithīn (Cairo: Dār al-Wa fā', 1993), 142.

${ }_{14}$ Muhammad Adīb Șāliḥ, Lamhat fī Ușūl al-Hadịth (Beirut: al-Maktab alIslāmiyyah, 1978), 84 . 
be done before firstly approached by the method of al-jam' wa altawfiq.${ }^{15}$ The fourth method is al-tawaqquf (leaving without any provisions). If those three methods above are not possible to be applied in resolving the conflicting hadith, the hadith experts must take a step by not giving any provisions upon such hadith, provided that those hadith are not in contradiction to the matters of halal and haram, compulsory and haram, and sunnah and makruh, which is unlikely accepted both. ${ }^{16}$

Theoretically, I adopt the science of understanding/ hermeneutics by Heidegger. Hermeneutic theory is used to understand the meaning of a text as a socio-cultural phenomenon, because in understanding a text, one shall need three subjects, namely the text itself, writer of the text, and reader of the text. The approach of mukhtalaf al-hadith developed by hadith expert also becomes the main instrument in this research. Such a method is formulated by hadith experts for understanding some conflicting hadith in order to get the points of convergence from such contradiction. Historical approach is also used to reconstruct the development of hadith study in Indonesia before and after $20^{\text {th }}$ century, including the form of popular hadith studies in Indonesia before $20^{\text {th }}$ century and any studies developed in the $20^{\text {th }}$ century. Hence, this study presents the periodization of hadith study development in Indonesia.

\section{The Development of Hadith Study in Indonesia}

In Nusantara (archipelago), any efforts to revitalize the teachings of the Prophet found in hadith have taken place since the second half of $17^{\text {th }}$ century, along with the arrival of renewal ideas (modernization) that emphasize al-Qur'an and hadith as the source of Islamic teachings. The scholars study hadith from inspiration and knowledge on the ways that lead the Muslim society to socio-moral reconstruction. However, until the

15 Hammād, Mukhtalaf al-Hadìth, 227.

16 Muḥammad ibn 'Abd al-Raḥmān ibn Muḥammad Al-Sakhāwi, Fatḥ alMugìth bi Sharh Alfiyyat al-Hadìth lial-'Irāqī (Cairo: Maktabah al-Sunnah, 2003), 70. 
beginning of $20^{\text {th }}$ century, the study of hadith in Indonesia is still less popular. ${ }^{17}$

One of the earliest Malay hadith books, Hidāyāt al-Habìb alTarghì w wa-al-Tarhì , is written by Nuruddin al-Raniri. The lack of studies on the tradition of writing hadith, including upon the text of this Hidāyāt al-Habìb, is highly influenced by the limited access to primary sources in the form of handwritten scripts (manuscript) regarding this field. Hidāyāt al-Habīb was written on 6 Syawal 1045 $\mathrm{H} / 14$ March $1636 \mathrm{M}$, a book consists of 831 hadith from various sources, such as Bukhārī, Muslim, Turmudhī, and many others. ${ }^{18}$

The study of hadith in Nusantara had shown its existence between the $17^{\text {th }}$ and $19^{\text {th }}$ century despite being limited. Some scholars discuss the science of hadith in their works, such as hadith classification of sahih, hasan, and da'if nothwithstanding its limitness in terms of the number and depth of analysis. For example, in the book of "Jawaban Syeikh Ahmad bin Muhammad Zayn al-Fatani tentang Hadis Memulai dan Menyudahi Makan dengan Garam" (the responses of Shaykh Ahmad bin Muhammad Zayn alFatani regarding the hadith on the beginning and finishing eating), where Shaykh Ahmad answered such a matter with a long explanation based on the science of mustalah hadith while taking into account the 'Ilm Rijäl al-Hadìth' 19 .

In Tanqịh al-Qawl al-Hathīth bi Sharh Lubāb al-Hadīth, Nawawi al-Bantani emphasized the importance of transmission (sanad) in a hadith by giving emphasis on the names of narrators in determining the validity of transmission. The book of Matāli' alAnwār wa Majāmi' al-Azhar by Shaykh Usman Jalal al-Din alKalantani discusses the science of hadith in its introduction. The book of Manhaj Dhawi al-Nazar by Shaykh Mahfuz al-Tarmasi is a

17 Agung Danarto, Kajian Hadis di Indonesia Tahun 1900-1945 (Tela'ah terhadap Pemikiran Beberapa Ulama tentang Hadis) (Yogyakarta: Proyek Perguruan Tinggi Islam IAIN Sunan Kalijaga, 2000), 8.

18 Read Fathurrahman, "The Roots."

${ }^{19}$ Oman Fathurrahman and Munawar Holil, Katalog Naskah Ali Hasjmy Aceh (Jakarta: PPIM dan Yayasan Pendidikan dan Museum Ali Hasjmy Banda Aceh, MasyarakatKomunitas Nusantara [MANASSA], Centre for Documentationand Area-Transcultural Studies [C-DATS], Tokyo University of Foreign Studies [TUFS], 2007), 22. 
book of Mustalah al-Hadith which is fairly complete. The study on hadith science, including its sanad, is also mentioned by him in his other works, namely al-Minhah al-Khayriyyah fì Arba'ìn Hadìth min Ahāeìth Khayr al-Bariyyah, Kifāyah al-Mustafìd fì mā 'Alā minalAsānī̀d.

In addition, the book of al-Fawaid al-Bahiyyah by Nuruddin Muhammad ibn Ali ibn Hasanji is also regarded as the work of scholar in Nusantara in the field of hadith during the early period. This book consists of one volume with 332 pages and 831 hadith of Prophet Muhammad SAW. This book was already printed and published in Egypt in $1346 \mathrm{H} / 1927 \mathrm{M}$. These 831 hadith are explained or described by using Malay language. Substantively, these hadith are, by its writer, discussing on how to practice the virtues, and conversely, are also presenting hadith of advices on how to stay away from the evil. In other words, it can be said that the hadith contained in this book tend to have relation with the wisdoms of human's experiences in day-to-day life. ${ }^{20}$

Another example is Mahfudz Termas which is known through one of his works, namely Manhaj Dhawī al-Nazar fì Sharh alManżūmāt 'Ilm al-Athar. This Arabic book is a commentary upon the book of al-Manzūmāt 'ilm al-Atharby Jalāl al-Dīn al-Suyūtī, and it is successfully made Mahfudz Termas as one of the leading scholars in Nusantara, especially in the field of hadith. As a result, such book is referred by many Muslim scholars in Islamic world as a whole. ${ }^{21}$

Afterwards, the works of T.M. Hasbi Ash-Shiddieqy also give another color to the dynamics of hadith study in Nusantara in the beginning of $20^{\text {th }}$ century. One of his works is Sejarah dan Pengantar Ilmu Hadis (The history and introduction to the science of hadith). This book explains the history in the growth and development and the science of hadith. According to its author, this book is an introduction for Mutiara Hadith, which is also composed by this author.

\footnotetext{
${ }^{20}$ Muhajirin, "Transmisi Ha dis di Nusantara: Peran Ulama Hadis Nusantara Muḥammad Maḥfūz al-Tarmasī”' (Dissertation, UIN Syarif Hidayatullah, 2009), 197.

${ }^{21}$ Read Fathurrahman, "The Roots."
} 
We can observe that within the period of $17^{\text {th }}$ to $19^{\text {th }}$ century, Islamic education was still given in its simplest form and not systemized yet. No data were found quite representative about the given curriculum of Islamic teachings. The in-depth and formal learning of hadith and 'Ulüm al-Hadìth has been seemingly not been conducted yet. Federspiel added that during the Dutch's colonialization, the study of hadith had not been discussed as an independent discipline of science. At that time, the discussion on hadith still became a part of other Islamic disciplines of science, such as fiqh. ${ }^{22}$

The scholars of $18^{\text {th }}$ and $19^{\text {th }}$ century continuously showed a large number of similar trends with any trends developed in the previous periods. While the pressure on hadith study continued, the reconciliation between Shari'a and Sufism progressively gained a stronger foundation. A significant development from the eighteenth century was lots of leading scholars giving em phasis on the reconciliation between those four schools of fiqh. ${ }^{23}$

In the early $20^{\text {th }}$ century, the hadith books were still not made as source of reference, because this study was considered new in the education in Indonesia, especially in Islamic boarding schools. At that time, the hadith scholars began to give more attention on the study of hadith by collecting the books of hadith to be translated and presented as materials to be taught in educational institutions, such as Madrasa and Islamic boarding school. No books of hadith written by Indonesian scholars in the beginning of $20^{\text {th }}$ century made as the basic study of hadith in Islamic boarding school became the evidence at that time. The study of hadith in Indonesia was still in introduction phase.

Until 1980s, there were, at least, four types (genre) of hadith literature in Indonesia. The first type is the literature of hadith science which contains the analysis of any hadith developed in early days of Islam to determine its authenticity and falsity. The second type is the literature of hadith book which translates the

\footnotetext{
${ }^{22}$ Howard M. Federspiel, The Usage of Tradition of the Prophet in Contemporary Indonesia (Arizona: Program for SAS, 1993), 5.

${ }_{23}$ Azyumardi Azra, Jaringan Ulama Timur Tengah dan Kepulauan Nusantara Abad XVII dan XVIII (Bandung: Mizan, 1998), 163.
} 
books of hadith within the classic era (620-1250) and middle days of Islam (1250-1850). The third type is anthology of the selected hadith taken from various hadith book collections selected and rewritten by Indonesian writers. Further, the fourth type is a collection of hadith used as the source of law and material of teaching in Islamic schools. ${ }^{24}$

On the other hand, a great number of studies on hadith have emerged delineating the content of hadith collected in one master book of hadith or a book of collected hadith. The works of $\mathrm{Al}$ Khil 'ah al-Fikriyyah Sharhal-Minhah al-Khayriyyah and al-Tabyin alRāwì Sharh Arba ìn Nawawì, for example, have given an actual contribution to this field. Both works have added a new color in the study of hadith in Indonesia during the early days of $20^{\text {th }}$ century. Analytic method (Tahlili $\bar{l})$ ) used by Mahfudz al-Tarmasi in explaining the prophet's hadith in his book entitled Al-Khil 'ah alFikriyyah Sharh al-Minhah al-Khayriyyah, in detailed, along with the description of the biography of hadith narrators, includes the full name, nickname, title, place and date of birth. It also covers address, and death, degree of the hadith, takhrij of the hadith, analysis on words and sentences, as well as various information relating to the hadith. Meanwhile, Kasyful Anwar in his work, alTabyīn al-Rāwì Sharh Arba 'inn Nawawī, preferred global method $(\operatorname{Ijm} \bar{a} l \bar{l})$ to the other methods in explaining the hadith by giving emphases on a brief explanation and focusing on the hadith contents. Both works also use the analysis method in explaining hadith, along with language analysis and content analysis that refer to the verses of Al-Qur'an and hadith of the prophet as the basis for its analysis.

\section{Muhajirin and His Work on Hadith}

Muhajirin Amsar al-Dari is one of the scholars of hadith of the early twentieth century of modern Indonesia. He was born and raised in Kampung Baru, Cakung, East Jakarta, on November 24, 1924. When one mentioned a trio of religious science warriors

${ }^{24}$ Muh. Tasrif, "Studi Hadis di Indonesia (Telaah Historis terhadap Studi Hadis dari Abad XVII - Sekarang)," Jurnal Studi Ilmu-ilmu Al-Quran dan Hadis 5, no. 1 (January 2004): 113. 
from Bekasi in the era of 60s, the name of Syaikh Muhammad Muhajirin Amsar al-Dari is one of them, and the rest two are K.H. Noer Ali and K.H. Abdurahman Sodri. In the first Islamic boarding school in Bekasi, in 1963, not far from the location of an Islamic boarding school named Bahagia, Syaikh Muhammad Muhajirin Amsar al-Dari found an Islamic boarding school named Annida Al-Islami ${ }^{25}$.

On 4 Dzulqa'dah of $1366 \mathrm{H}$ or August 1947, Shaykh Muhammad Muhajirin departed from Indonesia by a ship heading to Jeddah from which he performed the pilgrimage to Mecca. The early struggle of Shaykh Muhammad Muhajirin in seeking knowledge began when he lived in the house of Shaykh 'Abdul Ghani Jamal. After staying there for few times, in the middle of the year, he moved to Asrama Jailani located inside "Mudda ' $\imath$ ". When he stayed there, at first, he studied to Shaykh Muhammad Ahyad who replaced Shaykh Muchtar al-Tarid al-Jawî at Mosque of alHaram. In addition, Shaykh Muhammad Muhajirin also learned from other teachers during his study in Mecca and Medina. They are Shaykh Hasan Muhammad al-Masshat, Shaykh Zayni Bawean, Shaykh Muhammad 'Ali b. Husain al-Malikiy, Shaykh Mukhtar Ampetan, Shaykh Syed 'Alawi b. 'Abbas al-Malikiy, Shaykh Ibrahim al-Fataniy, Shaykh Amin al-Qutbiy, Shaykh Ahmad Manshuriy, Shaykh Muhammad Yasin al-Fadaniy, Shaykh Muhammad Amin al-Sinqitiy, and Shaykh 'Abdurrahman alAfriqiy. On Thursday, August 6, 1955 or exactly on 19 Safar 1375 Hijriyah, he arrived at the homeland of Indonesia, at the request of his mother. In his effort to practice and spread his knowledge, he established an educational institution and Islamic boarding school from the level of Tsanawiyah (1-3 grades) to University by the name of Annida Al-Islamiy. Shaykh Muhammad Muhajirin died in 2003. ${ }^{26}$

Shaykh Muhammad Muhajirin is a very prolific scholar. He had written about thirty books, and all of them are in Arabic. His

\footnotetext{
${ }^{25}$ Muhammad Muhajirin al-Dari Bekasi Amsar, Sejarah Singkat Perjalanan Hidup Syeikh Muhammad Muhajirin Amsar Addary (Bekasi: Pesantren Annida AlIslamy Bekasi, 2007), 7-20.

${ }^{26}$ Ibid., 5.
} 
work are compulsory resources for the students studying in his Islamic boarding school from the thanawiyyah (equivalent to first grade) to almarhalah al-'ulya (equivalent to pre-siswazah). The Annia Islamic boarding school has listed the works of its founder, Syekh Muhammad Muhajirin, as the evidence indicating that the Syekh is a sort of productive Islamic scholar. Aside from being the compulsory sources in the boarding school, his works are also reviewed and learnt in Majlis Taklim and several education institutions in Bekasi and Jakarta he organized. His works are as followings ${ }^{27}$ :

1. Miṣbāḥ al-Zulām Sharḥ Bulūg al-Marām, 8 Volumes (fiqh hadith)

2. Ị̇āḥ al-Mawrūd, 2 Volumes (ushul fiqh)

3. Muḥammad Rasūl Allāh (tarikh/ history)

4. Mir'at Al-Muslmīn fī Sīrat Khulafā' al-Rāshidīn (tarikh/ history)

5. Al-Muntakhab Min Tārīkh Dawlah Umayyah (tarikh/history)

6. Qawā'id al-Khams al-Bahiyyah (qowaid fiqh)

7. Al-Istidhkār (musthalah hadith/ushul hadith)

8. Ta'līqāt 'alā Matn al-Jawharah, 2 Volumes (tauhid)

9. Mukhtārat al-Balāgah, 2 Volumes (balaghah)

10. Qawā‘id al-Nahwiyyah, 2 Volumes (nahwu/Arabic grammar)

11. Al-Qawl Al-Hathīth fī Mușțalah Al-Hadīth (musthalah hadith/ ushul hadith)

12. Taysīr al-Ușūl fī 'Ilm al-Ușūl (ushul fiqh)

13. Qawā'id al-Manțiq, 2 Volumes (mantiq)

14. Muṭāla'at MaḥfūZāt

15. Takhrīj al-Furū' 'alā al-Ușūl

16. Taṭbīq al-Āyāt bi al-Hadīth

17. Al-Faỵ̣ fī 'Ilm al-Farā'ị̣ (faroid)

These work show that his knowledge is not only in one scientific field, but also it includes several Islamic knowledge. All books were printed privately by him. But, this time, some publishers have published some of his works. Unfortunately, his books are not widely known. It is, perhaps, because those books

${ }^{27}$ Ibid., 21-22. 
were printed independently and not sold widely; thus its spread is only limited to his students and the people that knew him.

The most significant expertise of Shaykh Muhajirin is the study of hadith. He studied long enough to Shaykh Muhammad Yasin bin 'Isa al-Fadani at Dar al-'Ulum, Mecca. Shaykh Muhammad Yasin al-Fadani was known among the world's scholars as one of the greatest Muhaddith of this century. Shaykh Yasin got the epithet as Suyuti Zamanihi (Imam Suyuti in his day). In addition, he was also titled as "Musnid al-Dunya". It was a very rare title, and even no one had such a title in his era. He had almost all sanad of Islamic scientific books.

The background behind the birth of Miṣbāh al-Zulām was originated from an admiration of the book of Bulügh al-Marām by Ibn Hajar. In his view, the presence of Bulügh al-Marām as a book of hadith ahkam was a phenomenal work. Shaykh Muhajirin said that lot of scholars after the generation of Ibnu Hajar made his work as a reference in the search of hujjah relating to the law of Islam or the study of hadith of law itself resulting in explanatory books (sharah).

The book of Miṣbāḥ al-Zulām, as a script, was written when Shaykh Muhajirin was in Mecca. Then, the improvement of such writing was completed in 1972 and it was firstly published in 1985 by the University of Annida Al-Islamiy. The book of Miṣbāh alZulām, in its old printed version, consisted of eight volumes, in which Volume I had 279 pages, Volume II had 293 pages, Volume III had 270 pages, Volume IV had 258 pages, Volume V had 204 pages, Volume VI had 276 pages, Volume VII had 236 pages, and Volume VIII had 284 pages. Meanwhile, the new version consisted of four volumes, in which Volume I had 408 pages, Volume II had 390 pages, Volume III had 328 pages, and Volume IV had 415 pages. The orders of book, chapter, and the number of the hadith are included in the book of Bulūg al-Marām, consisting of 16 titles of book, 76 titles of chapter, and 1597 hadith. ${ }^{28}$ Shaykh Muhajirin himself, in the introduction of his book, told about the main

${ }^{28}$ See Muhammad Muhajirin al-Dari Bekasi Amsar, Miṣbāḥ al-Zulām Sharh Bulūg al-Marām min Adillat al-Aḥkām (Bekasi, 1991). 
reference source in Miṣbāh al-Zulām was all syarah books of alKutub al-Sittah plus popular fiqh books and its usul fiqh books.

In general, the syarah conducted by Shaykh Muhajirin had already included sanad and matn although the discussion on the chance of transmission was very simple. According to Shaykh Muhajirin, it was because the discussion of sanad did not become the main focus of Misbah alzulam. He gave emphases on its discussion of the law of Islam. ${ }^{29}$

\section{Ikhtiläf al-hadìth in Muhajirin's View}

In the early $20^{\text {th }}$ century, the books of hadith have not been made as a main source of reference yet in Islamic boarding schools. At that time, the scholars of hadith begin to give more attention to the study of hadith by collecting the books of hadith which then were translated and made as the subjects taught in the education institution of madrasa and Islamic boarding school. No books of hadith were written by Indonesian scholars in the beginning of $20^{\text {th }}$ century, as the separate basic study of hadith in Islamic boarding schools. The study of hadith in Indonesia was still in the realm of introduction.

Such a fact can be described in the following table of the understanding method of Mukhtalaf al-Hadith according to Muhajirin in the book of Mișbāh al-Zulāmº:

\begin{tabular}{|c|l|c|c|c|c|}
\hline \multirow{2}{*}{ No } & \multicolumn{1}{|c|}{ Problem } & \multicolumn{3}{|c|}{ Method of Understanding } \\
\hline & & Al-Jam & Al-Naskh & Al-Tarjị & Al-Tawaqquf \\
\hline 1 & Size of the clean water & $\sqrt{ }$ & & & \\
\hline 2 & Basmalah in ablution (wudlu) & $\sqrt{ }$ & & & \\
\hline 3 & $\begin{array}{l}\text { Touching the skin of opposite } \\
\text { sexabrogates the ablution }\end{array}$ & $\sqrt{ }$ & & & \\
\hline 4 & $\begin{array}{l}\text { Touching the genital part } \\
\text { abrogate the ablution }\end{array}$ & & $\sqrt{ }$ & & \\
\hline 5 & $\begin{array}{l}\text { Punishment for marital } \\
\text { intercourse to husband and } \\
\text { wife during the fasting time } \\
\text { of Ramadan }\end{array}$ & & & & \\
\hline 6 & Shalat after Subuh and Asar & $\sqrt{ }$ & & $\sqrt{ }$ & \\
\hline 7 & Reading of adzan & & & $\sqrt{ }$ & \\
\hline 8 & Passing in front of the people & & & $\sqrt{ }$ & \\
\hline
\end{tabular}

${ }^{29}$ Dakir and Avivy, "Ketokohan Sheikh."

${ }^{30}$ Amsar, Miṣbāh al-Zulām. 


\begin{tabular}{|c|c|c|c|c|c|}
\hline \multirow{2}{*}{ No } & \multirow{2}{*}{ Problem } & \multicolumn{4}{|c|}{ Method of Understanding } \\
\hline & & Al-Jam' & Al-Naskh & Al-Tarjīh & Al-Tawaqquf \\
\hline & $\begin{array}{l}\text { performing Shalatabrogate } \\
\text { his/her Shalat }\end{array}$ & & & & \\
\hline 9 & Adorning the mosque & $\sqrt{ }$ & & & \\
\hline 10 & Re a ding Iftit $\bar{a} h$ & & & & $\sqrt{ }$ \\
\hline 11 & Basmalah in al-Fätihah & $\sqrt{ }$ & & & \\
\hline 12 & Qunut of Subuh & & & $\sqrt{ }$ & \\
\hline 13 & $\begin{array}{l}\text { Time for prostration of } \\
\text { forgetfulness (Sahwi) }\end{array}$ & & & & $\sqrt{ }$ \\
\hline 14 & $\begin{array}{l}\text { Number of rakat for } \\
\text { Qabliyyah Asar }\end{array}$ & & & & $\sqrt{ }$ \\
\hline 15 & The law of Shalat Witr & & & $\sqrt{ }$ & \\
\hline 16 & The law of communal prayer & & & $\sqrt{ }$ & \\
\hline 17 & Talking while speech & & & & $\sqrt{ }$ \\
\hline 18 & $\begin{array}{l}\text { Time for a pproved praying } \\
\text { (ijabah) }\end{array}$ & $\sqrt{ }$ & & & \\
\hline 19 & Steps for Shalat Khauf & & & & $\sqrt{ }$ \\
\hline 20 & $\begin{array}{l}\text { Shalat Qabliyyah and } \\
\text { Ba'diyyah of Shalat Ied }\end{array}$ & $\sqrt{ }$ & & & \\
\hline 21 & Eclipse prayer & & & $\sqrt{ }$ & \\
\hline 22 & Speeh at Shalat Istisq $\bar{a}^{\prime}$ & $\sqrt{ }$ & & & \\
\hline 23 & Men we aring silk & $\sqrt{ }$ & & & \\
\hline 24 & $\begin{array}{l}\text { The number of takbir when } \\
\text { performing Islamic funeral } \\
\text { prayer }\end{array}$ & & & $\sqrt{ }$ & \\
\hline 25 & Mourning at some one's death & $\sqrt{ }$ & & & \\
\hline 26 & Visiting grave & & $\sqrt{ }$ & & \\
\hline 27 & Visiting grave for women & $\sqrt{ }$ & & & \\
\hline 28 & Regretting the death & $\sqrt{ }$ & & & \\
\hline 29 & Zakat for the disbelievers & $\sqrt{ }$ & & & \\
\hline 30 & $\begin{array}{l}\text { Bekam (tra ditional he aling of } \\
\text { taking out dirt blood from the } \\
\text { body) abroga tes the fasting }\end{array}$ & $\sqrt{ }$ & & & \\
\hline 31 & Fasting on Saturday & & $\sqrt{ }$ & & \\
\hline 32 & Law of Umroh & & & & $\sqrt{ }$ \\
\hline 33 & Getting married while in $I h r a \bar{m} m$ & & & $\sqrt{ }$ & \\
\hline 34 & Selling the slave & $\sqrt{ }$ & & & \\
\hline 35 & Finding precious objects & $\sqrt{ }$ & & & \\
\hline 36 & Will to the heirs & $\sqrt{ }$ & & & \\
\hline 37 & $\begin{array}{l}\text { Right to choose for the slave } \\
\text { (wife) after being freed }\end{array}$ & & & $\sqrt{ }$ & \\
\hline 38 & $\begin{array}{l}\text { Remarried couples after } \\
\text { converting to Islam }\end{array}$ & & & $\sqrt{ }$ & \\
\hline 39 & Mahr & $\sqrt{ }$ & & & \\
\hline
\end{tabular}




\begin{tabular}{|c|c|c|c|c|c|}
\hline \multirow{2}{*}{ No } & \multirow{2}{*}{ Problem } & \multicolumn{4}{|c|}{ Method of Understanding } \\
\hline & & Al-Jam' & Al-Naskh & Al-Tarjị̣ & Al-Tawaqquf \\
\hline 40 & Blowing out the drinks & $\sqrt{ }$ & & & \\
\hline 41 & $\begin{array}{l}\text { Announcing triple talaq } \\
\text { (repudiation) at one time }\end{array}$ & $\sqrt{ }$ & & & \\
\hline 42 & Feeding size to be Mahram & & & $\sqrt{ }$ & \\
\hline 43 & $\begin{array}{l}\text { Qisas (re taliation in kind) for } \\
\text { parents who kills their } \\
\text { children }\end{array}$ & & & $\sqrt{ }$ & \\
\hline 44 & $\begin{array}{l}\text { Qisas (re taliation in kind) for } \\
\text { killing the disbelievers }\end{array}$ & $\sqrt{ }$ & & & \\
\hline 45 & $\begin{array}{l}\text { Fines for committing } \\
\text { mistakes }\end{array}$ & & & & $\sqrt{ }$ \\
\hline 46 & $\begin{array}{l}\text { Punishment for being murtad } \\
\text { (apostasy) }\end{array}$ & & & $\sqrt{ }$ & \\
\hline 47 & $\begin{array}{l}\text { Ensuring the confession of an } \\
\text { offender }\end{array}$ & & & $\sqrt{ }$ & \\
\hline 48 & $\begin{array}{l}\text { The number of lashes for } \\
\text { unmarried adulterer }\end{array}$ & $\sqrt{ }$ & & & \\
\hline 49 & Fighting an old disbeliever & $\sqrt{ }$ & & & \\
\hline 50 & Eating $D a b b$ (Lizard) & & & $\sqrt{ }$ & \\
\hline 51 & Law of sacrifice & & & $\sqrt{ }$ & \\
\hline 52 & $\begin{array}{l}\text { The number of goats for } \\
\text { a qiqah of son }\end{array}$ & $\sqrt{ }$ & & & \\
\hline 53 & Drinking while standing & $\sqrt{ }$ & & & \\
\hline 54 & $\begin{array}{l}\text { Divisive people will not go to } \\
\text { heaven }\end{array}$ & $\sqrt{ }$ & & & \\
\hline
\end{tabular}

Muhajirin uses four methods for understanding contradiction of hadith. From 54 cases of contradictions in the book of Miṣba a h alZulām, Muhajirin uses the method of al-Jam' as much as 27; alNaskh = 3; al-Tarjih = 17; and al-Tawaqquf $=7$. Half of those cases (in percentage) are settled by compromising the conflicting hadith. Almost one-thirds of those cases are settled by favoring one hadith compared to another hadith. Meanwhile, at a very little occassion, Muhajirin uses the method of hadith elimination due to another hadith. And for some cases, he does not give any comments firmly from their writings. He only describes several views from the scholars relating to the understanding of such conflicting hadith.

Among the examples of hadith settled by way of a compromise between two or more conflicting hadith are some histories in the reading of Basmallah when performing shalat. First 
hadith explains that according to the information given by 'Aisyah, the Prophet does not read basmalah after takbir, but he directly begins with al-Fatihah by reading of "Al-Hamd li Allah Rabb al"Álamin" (until the end of hadith). As narrated by Muslim:

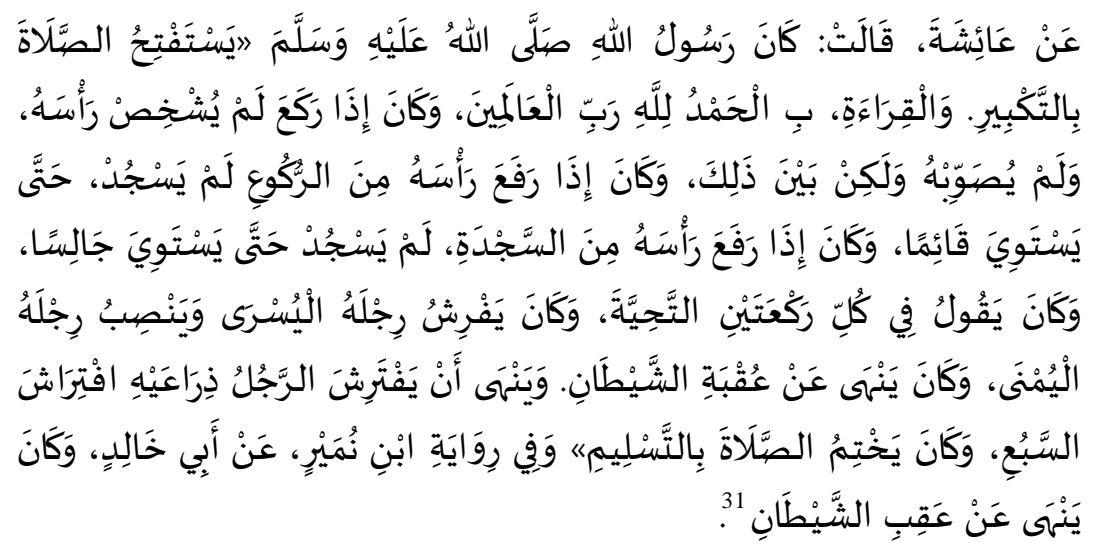

'A'isha reported: The Messenger of Allah began prayer with the takbir (Allah is most great) and with reciting "Praise be to Allah, the Lord of the Universe". And when he bowed, he neither raised up nor lowered down his head, but kept it between the two (conditions). And when he raised his head after bowing, he did not prostrate himself until he stood up straight; and when he raised his head after prostration, he did not prostrate (the second time) until he sat down properly; and he recited al-tahiyyat after every pair of $r a k^{\prime} a$; and when he sat, he spread out his left foot and raised his right. He forbade to sit like the sitting of the devil, and to spread out to hands (on the ground in prostration) like animals. He used to finish prayer with uttering the salutation.

The second hadith explains that according to Ummu Salamah, the Prophet's reading when shalat is "Bismillah al-Rahmān al-Rahìm. Al-Hamd li Allāh Rabb al-'Ālaminn" (until the end of hadith). As narrated by Abu Daud:

${ }^{31}$ Abū al-Ḥusayn 'Asākir al-Dīn Muslim ibn al-Ḥajjāj al-Naysābūrī, Ṣaḥịh Muslim (Beirut: Dār Ihyā’ al-Turāth al-'Arabī, n.d.), 1/357. 


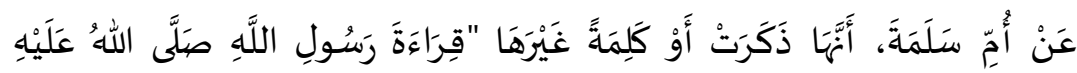

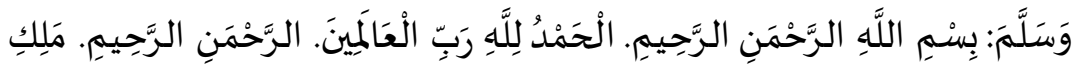

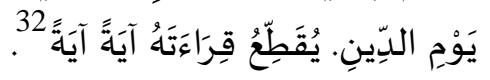

Umm Salamah Reported: The Messenger of Allah used to recite: "In the name of Allah, the Cherisher and Sustainer of the worlds; most Gracious, most Merciful; Master of the Day of Judgment," breaking its recitation into verses, one after another

In this case, Muhajirin Amsar gives comment:

$$
\text { المتضمن هذا الحديث (حديث عائشة) الاستفتاح بسورة الحمد لله رب العالمين }
$$

Meaning: Hadith by 'Aisyah is possibly leading to a meaning that reading al-Fatihah starting from " Al-Hamd li Allāh Rabb al"Álaminn" indicates the reading of basmalah. ${ }^{33}$

Among the examples of hadith settled by way of elimination is in the case of fasting on Saturday and Sunday. There is a hadith explaining that the Prophet is fasting on Saturday and Sunday for couple of times, even frequently. But, the Prophet also said that those two days are the feast day of idolatrous people. As narrated by Ibn Khuzaymah in his Sahih:

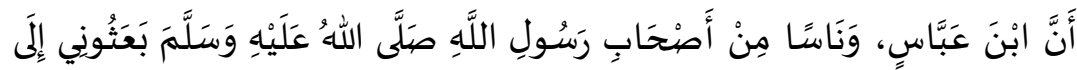

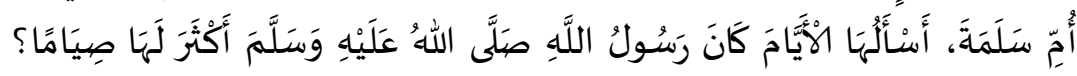

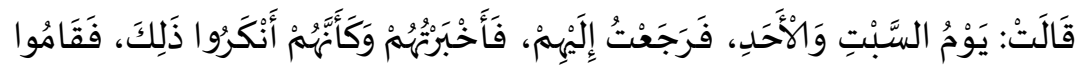

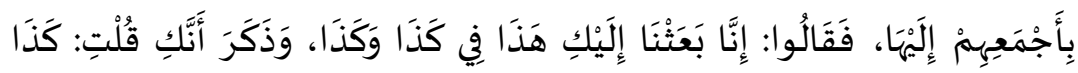

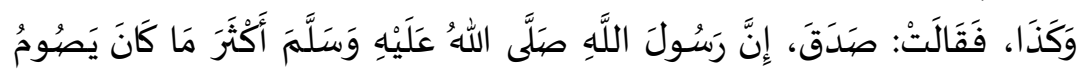

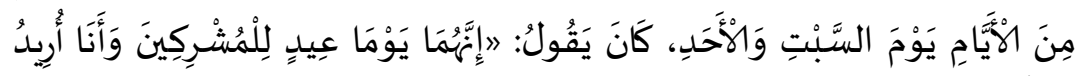

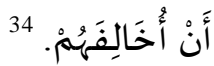

32 Abū Dāwūd Sulaymān ibn al-Ash'a th as-Sijistānī Abū Dā wūd, Sunan Abū Dāwūd (Beirut: al-Maktabah al-'Așriyyah, n.d.), 4/37.

${ }_{33}$ Amsar, Miṣbāh al al-Ẓulām, 15/2.

${ }_{34}$ Muḥammad ibn Isḥāq Ibn Khuzaymah, Ṣaḥ̄h ibn Khuzaymah (Beirut: alMaktab al-Islāmīi, n.d.), 3/318. 
From Kuraib, Verily Ibn 'Abbas and a group of Sahaba sent me on Umm Salamah. I asked about the Prophet fasting, Umm Salamah said: "On Saturday and Monday" then I go back and spread the news of Umm Salamah, but they do not believe it. They went to Umm Salama and said that we have sent someone for this purpose, he told me that you said like this. Umm Salamah said: "absolutely Saturday and Monday is a feast for idolatrous people, and I would like to differ with them.

Muhajirin gives comment as follow:

$$
\text { وأول الأمر، وتقدمت الحديث: كان أكثر ما يصوم من الأيام يوم السبت محمول على أنه في }
$$

Muhajirin understands that the words "the prophet often fasted on Saturday" become a clue that such matter is done by the prophet long before his sayings stating "actually those both days are the feast days of idolatrous people". ${ }^{35}$

Among the examples of hadith settled by means of favoring one hadith compared to another hadith is in the case of a person performing shalat whose place of prostration/ shalat is passed by another person or an animal. First hadith explains that a person's shalat becomes void if not giving a barrier at its place of prostration/ shalat, then passed by a women, donkey, and black dog. As narrated by Muslim:

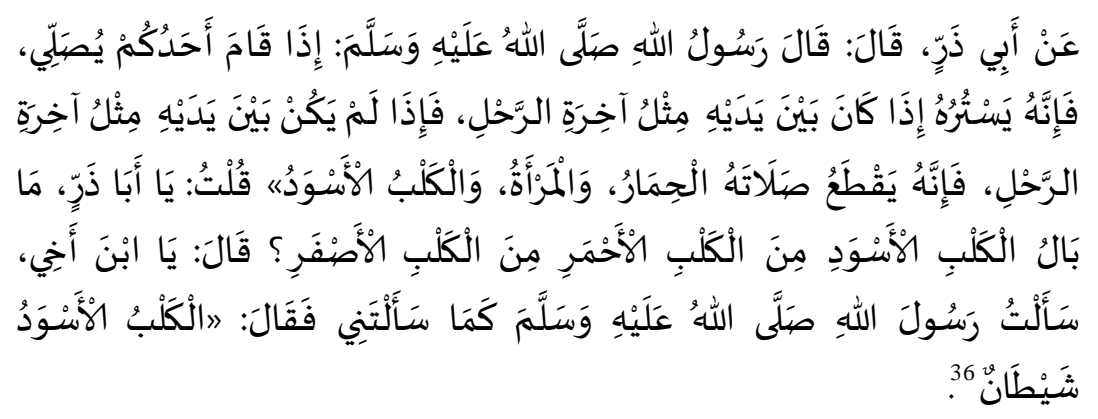

The messenger of Allah said: "When anyone of you stands to pray, then he is screened if he has in front of him something as high as the back of a camel saddle. If he does not have something

35 Amsar, Miṣbāḥ al-Zulām, 1/184.

36 al-Naysābūrī, Șahīh Muslim, 1/365. 
as high as the back of a camel saddle in front of him, then his prayer is nullified by a woman, a donkey or a black dog." I (one of the narrators) said: "What is the difference between a black dog, a yellow one and a red one?" He said: I asked the Messenger of Allah just like you and he said:"The black dog is a shaitan.

And the second hadith explains that someone's prayer will not be void by anything. As narrated by Abu Daud:

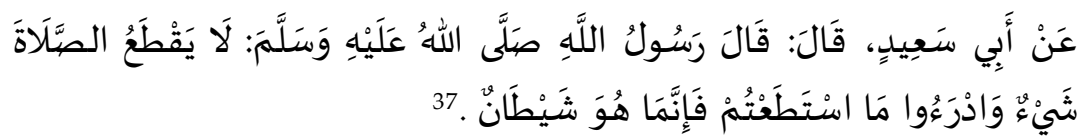

Abu Sa'id reported: There is nothing that can undo prayer and reject those who want to pass in front of you as much as you, because he (is forced to pass in front of the prayer) is the devil.

Muhajirin gives comment as follow:

$$
\begin{aligned}
& \text { لما نزعت الأحاديث في الشيئ الذي يقطع الصلاة نظرا إلى ما عمل به أصحاب } \\
& \text { رسول الله صلى الله عليه وسلم، لأن هؤلاء أدرى بواقعة الحال. }
\end{aligned}
$$

Muhajirin sees that both hadith must return its understanding to what the Companions do, because they knew about the intention contained in the Prophet's hadith. Ibn 'Abbas once narrated a hadith that explained about the cancelled shalat when others passed in front of its place of prostration. But, Ibn 'Abbas once decreed that after the prophet died, a donkey, dog and women that passed in front of a person performing shalat would not abrogate that prayer. In addition, 'Aisyah was also angry when she heard some of his companions said about the prophet's hadith that woman who passed in front of the prayer would cancel the shalat. She said: "Did you equate us with donkeys and dogs?". ${ }^{38}$

Among the examples of hadith settled by way of not compromising, not eliminating one of them, and also not favoring one of the them, but not giving definitive explanation, and instead giving explanation upon each content of the conflicting hadith in order to illustrate that both hadith are well acceptable, according to the tendency of its reader, is in the case of reading iftitah

${ }^{37}$ Abū Dāwūd, Sunan Abū Dāwūd, 1/191.

${ }^{38}$ Amsar, Miṣbāh al-Ẓulām, 1/182. 
(opening supplication) in prayer. First hadith explains that the reading of iftita in shalat is "Wajjahtu Wajhiya li al-Ladhi Fațara alSamāwāt wa al-'Ard until the end of the prayer". As narrated by Muslim:

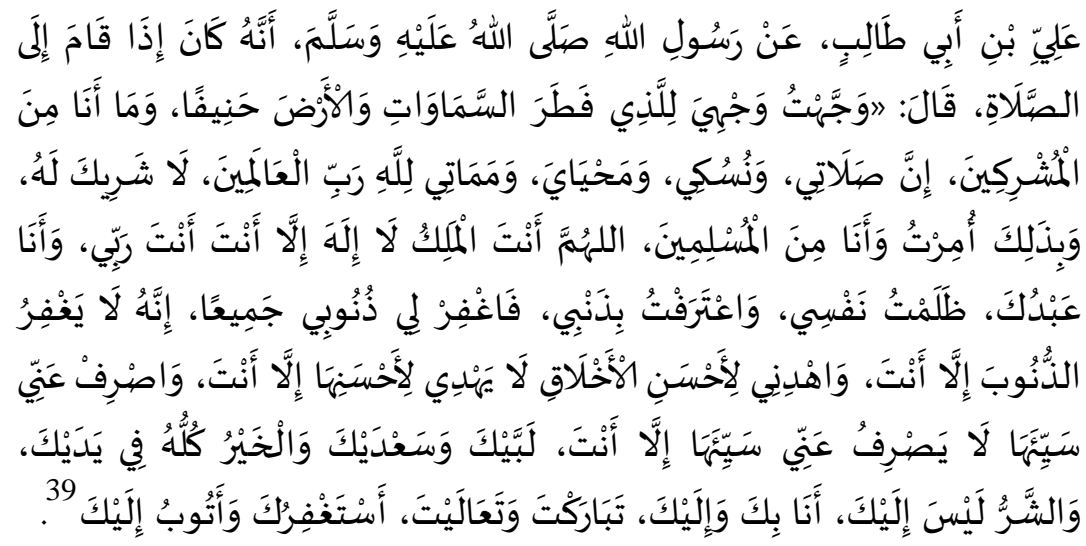

Reported 'Ali Bin Abi Talib: That when the Prophet stood for prayer, he would make the takbir (rising hand in prayer) and then say, "I have turned my face to the One Who created the heavens and the earth as a sincere submissive (person), and I am not one of the polytheists. My prayers, my sacrifice, my life and my death are all for Allah, the Lord of the Worlds; No partner with Him (in all that). That is what I have been ordered and I am of those who submit. O Allah, you are the King and there is no Lord besides You. You are my Lord and I am Your slave. I have wronged my soul and You are aware of my sins, so forgive all of my sins. No one forgives sins save You. Guide me to the best character. No one can guide to the best of that save You. Turn me away from its evil, and no one can turn me from its evil save You. At your beck and call, here I am (to serve you) all the good is in Your hands and evil is not to You. And I am for You, and to You are the blessings and the exaltedness. I seek your forgiveness $\mathrm{O}$ Allah and return unto You.

And the second hadith explains that the reading of iftitah in shalat is "Allāhumm Bā'id Baynī wa Bayn Khațayāy kamā Bā'adta Bayn al-Mashriq wa al-Magrib until the end of the prayer". As narrated by Muslim:

\footnotetext{
39 al-Naysābūrī, Șaḥịh Muslim, 1/534.
} 


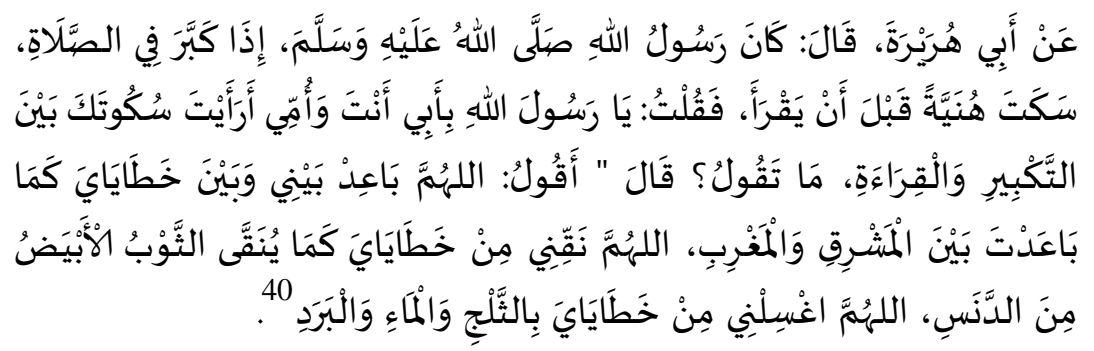

Reported Abu Hurairah, "When the Prophet made the opening takbir, he would be quiet for a little while before his recitation. I asked him, 'O Messenger of Allah, may my father and mother be sacrificed for you, why are you quiet between the (opening) takbir and your recitation? What do you say (at that time)?' He said, 'I say, "O Allah, make the distance between me and my sins as far as you have made the distance between the East and the West. $\mathrm{O}$ Allah, cleanse me of my sins as a white garment is cleansed of dirt. O Allah, purify me from my sins by snow, rain and hail.

And the third hadith explains that the reading of iftita in shalat is "Subhannaka Allāhumm wa bihamdik until the end of the prayer". As narrated by Nasai:

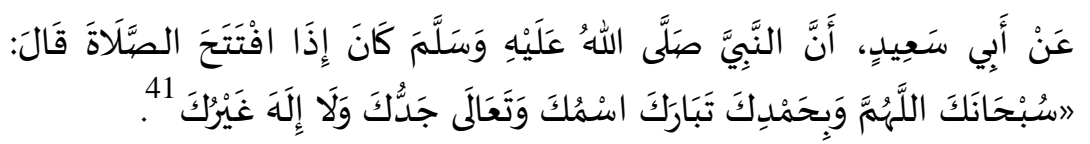

Narrated Abu Saeed: He said: When the messenger of Allah used to stand in prayer, he would say: "Glory be to You, O Allah, and to You is the praise. Blessed is Your name and most high is Your honor. There is no Lord besides You".

And the fourth hadith explains that the reading of iftitah in shalat is "A'ūdhu bi Allāhal-Samī' al-'Alìm min al-Shayțān al-Rajīm min Hamzih wa Nafkhih wa Nafthih". As narrated by Abu Daud:

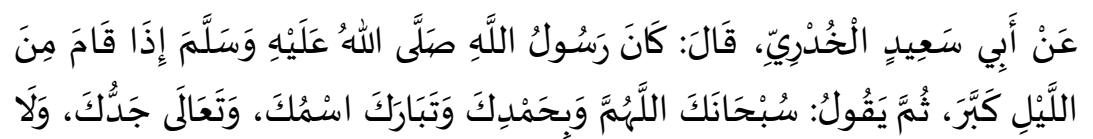

${ }^{40}$ Ibid., $1 / 419$.

${ }^{41}$ Abū 'Abd al-Raḥmān Aḥmad ibn Shu'ayb ibn 'Alī ibn Sīnān al-Nasā'̄î, Sunan al-Nasā' (Halb: Maktab al-Maṭbū'at al-Islāmiyyah, 1986), 2/132. 


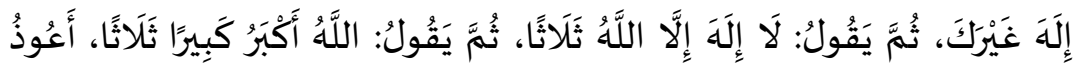

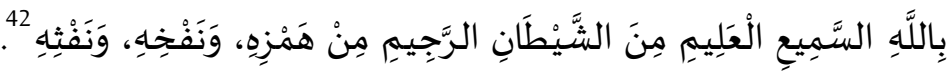

Narrated Abu Saeed: He said: When the messenger of Allah used to stand in prayer in the late night, he would say the takbeer and say: "Glory be to You, O Allah, and to You is the praise. Blessed is Your name and most high is Your honor. There is no Lord besides You." "O Allah, I seek refuge in You from Satan the accursed and from his pricking, spittle and puffing".

Muhajirin gives comment as follow:

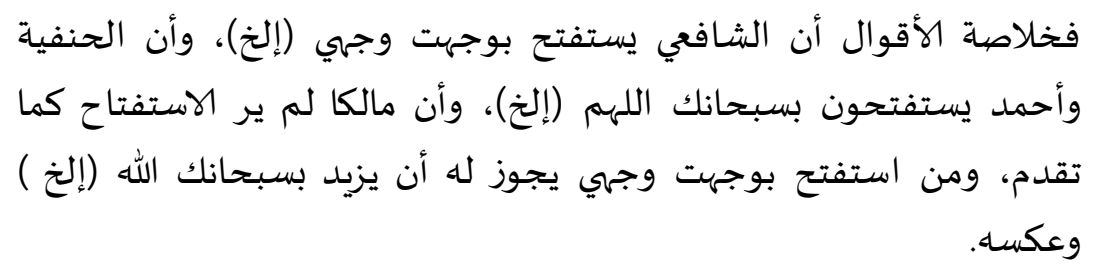

Seeing those four hadith above, Muhajirin explains that each hadith becomes the guideline for each of the schools (mazhab) in performing shalat. The school of Syafi'iyah uses the reading of "Wajjahtu Wajhiya", while the schools of Hanafiyah and Ahmad use the reading of "Subhanaka Allahumma". Afterward, Muhajirin confirms that each of the schools may add another prayer included in the text of hadith made as the guideline for other schools. ${ }^{43}$

The above examples give an illustration that the case of contradiction hadith has become an emphasis in the study of hadith commentaries in Indonesia during the $20^{\text {th }}$ century, and it also places Muhajirin as one of the scholars in Nusantara contributing to the development study of hadith in Indonesia.

The study given by Muhajirin is very interesting, because he attempts to get into the study of hadith that is quite difficult and not easy for an expert of hadith. Muhajirin had got a lot of things when travelling for learning Islamic knowledge in Haramain. It makes him as a figure with high capability in the field of hadith. Later, He developed the knowledge he got in Haramain in his works in the field of Syarah Hadith.

${ }^{42}$ Abū Dā wūd, Sunan Abū Dāwūd, 1/206.

${ }^{43}$ Amsar, Miṣbāh al-Ẓulām, 1/214. 
From the example above, Muhajirin attempts to understand the contradicting hadith at his best. Thus, no hadith with a strong sanad was neglected, either by removing or excluding it. Muhajirin attem pts to think of its understanding in order to make it as an alternative between such conflicting hadith.

\section{Conclusion}

The methodology of understanding mukhtalaf hadith in Indonesia in the $20^{\text {th }}$ century established by Muhajirin tends to try to avoid the method of al-naskh (removing one hadith with another hadith). The author tends to find an acceptable way for both parties to resolve the contradicting hadith. Drawing on the 54 cases of conflicting hadith in the book of Mishbah al-Zulam, Muhajirin understood it by compromising such hadith into 27 cases, meaning that from $50 \%$ of the cases, he tried to compromise with his deep understanding upon any aspects in such cases.

The characteristics of the book of hadith commentaries in Indonesia in the $20^{\text {th }}$ century show a very significant development of the study of hadith. Muhajirin plays important role in this field of study by entering the area of Hadith Mukhtalaf, which was a very complicated area, since it was considered as the peak of nobility for a scholar of hadith. The finding of this study can become an entry point to further explore the study of the development of hadith in Indonesia in modern times which still receive a small attention from scholars.

\section{References}

Abdur-Rahman, M.A., Abdul Mutalib Embong, Muhammad Ridhuan Tony Lim Abdullah, Mashitah Sabdin, Raja Ahmad Iskandar Raja Yaacob, and Mohd Pisol Mat Isa. "Historical Review of Classical Hadith Literature in Malay Peninsula." International Journal of Basic and Applied Sciences 11, no. 2 (2011). Abū Dāwūd, Abū Dāwūd Sulaymān ibn al-Ash'ath as-Sijistānī.

Sunan Abū Dāwwīd. Beirut: al-Maktabah al-'Așriyyah, n.d. Al-Sakhāwi, Muhammad ibn 'Abd al-Raḥmān ibn Muhammad. Fath al-Mugìth bi Sharh Alfiyyat al-Hadīth li al-'Irāqì. Cairo: Maktabah al-Sunnah, 2003. 
Al-Shāfi'îi, Muḥammad ibn Idrīs. Al-Risālat. Cairo: Maktabat alHalabi, 1940.

Amsar, Muhammad Muhajirin al-Dari Bekasi. Miṣbāh al-Ẓulām Sharḥ Bulūg al-Marām min Adillat al-Aḥkām. Bekasi, 1991.

- - - Sejarah Singkat Perjalanan Hidup Syeikh Muhammad Muhajirin Amsar Addary. Bekasi: Pesantren Annida Al-Islamy Bekasi, 2007.

Azra, Azyumardi. Jaringan Ulama Timur Tengah dan Kepulauan Nusantara Abad XVII dan XVIII. Bandung: Mizan, 1998.

Brown, Jonathan A. C. "Criticism of the Proto-Hadith Canon: Al-

Daraqutni's Adjustment of the Sahihayn." Journal of Islamic Studies 15, no. 1 (January 1, 2004): 1-37.

van Bruinessen, Martin. "A Note on Source Materials for The Biographies of Southeast Asian Ulama." La Transmission du Savoir Dans le Monde Musulman Peripherique, Lettre d'information 17 (1997): 57-66.

- - - Kitab Kuning Pesantren dan Tarekat, Tradisi-Tradisi Islam di Indonesia. Bandung: Mizan, 1999.

Dakir, Jawiah, and Ahmad Levi Fachrul Avivy. "Ketokohan Sheikh Muhammad Muhajirin Amsar Al-Dary Sebagai Ilmuan Hadis Nusantara: Analisis Terhadap Kitab Miṣbāḥ Al-Ẓulām Sharḥ Bulūg Al-Marām." In Prosiding Nadwah Ulama Nusantara (NUN) IV, 231-236. Bangi, Selangar: University Kebangsaan Malaysia, 2011.

http://www.ukm.my/nun/prosiding\%20atas\%20talian.htm.

Danarto, Agung. Kajian Hadis di Indonesia Tahun 1900-1945 (Tela'ah terhadap Pemikiran Beberapa Ulama tentang Hadis). Yogyakarta: Proyek Perguruan Tinggi Islam IAIN Sunan Kalijaga, 2000.

bin Deraman, Fauzi, and Mohd Asmawi bin Muhammad. "KaryaKarya 'Ulum al-Hadith di Nusantara: Satu Sorotan." Al-Bayan Journal of Qur'an and Hadith Studies 8 (2013).

Fathurrahman, Oman. "The Roots of the Writing Tradition of Hadīth Works in Nusantara: Hidāyat Al-Habīb by Nūr Al-Dīn Al-Rānīrī." Studi Islamika Indonesian Journal for Islamic Studies 19, no. 1 (2012): 47-76.

Fathurrahman, Oman, and Munawar Holil. Katalog Naskah Ali Hasjmy Aceh. Jakarta: PPIM dan Yayasan Pendidikan dan Museum Ali Hasjmy Banda Aceh, Masyarakat Komunitas 
Nusantara [MANASSA], Centre for Documentationand AreaTranscultural Studies [C-DATS], Tokyo University of Foreign Studies [TUFS], 2007.

Federspiel, Howard M. The Usage of Tradition of the Prophet in Contemporary Indonesia. Arizona: Program for SAS, 1993.

Ghazali, Abdul Moqsith. "Ulama Arab dan Ulama Indonesia." Islamlib. Last modified Oktober 2008. Accessed February 11, 2016. http://islamlib.com/gagasan/islamnusantara/ulama-arabdan-ulama-indonesia/.

Hammād, Nafiz Husayn. Mukhtalafal-Hadìth Bayn al-Fuqahā' wa alMuhaddithīn. Cairo: Dār al-Wafā', 1993.

al-Nasā'î̀, Abū 'Abd al-Raḥmān Aḥmad ibn Shu 'ayb ibn 'Alī ibn Sīnān. Sunan al-Nasā'̀̄. Halb: Maktab al-Maṭbū'at alIslāmiyyah, 1986.

Ibn Khuzaymah, Muḥammad ibn Isḥāq. Șahīh ibn Khuzaymah. Beirut: al-Maktab al-Islāmī, n.d.

Ismail, M. Syuhudi. Hadis Nabi Menurut Pembela, Pengingkar, dan Pemalsunya. Jakarta: Bulan Bintang, 1995.

Muhajirin. "Transmisi Hadis di Nusantara: Peran Ulama Hadis Nusantara Muḥammad Maḥūz al-Tarmasī." Dissertation, UIN Syarif Hidayatullah, 2009.

al-Naysābūrī, Abū al-Ḥusayn 'Asākir al-Dīn Muslim ibn al-Ḥajjāj. Sahị̄h Muslim. Beirut: Dār Ihyā’ al-Turāth al-'Arabī,n.d.

Șāliḥ, Muḥammad Adīb. La mḥat fī Ușūl al-Hadīth. Beirut: al-Maktab al-Islāmiyyah, 1978.

Steenbrink, Karel A. “Beberapa Aspek Tentang Islam di Indonesia Abad 19." In Beberapa Aspek tentang Islam di Indonesia Abad 19. Jakarta: Bulan Bintang, 1984.

Tasrif, Muh. "Studi Hadis di Indonesia (Telaah Historis terhadap Studi Hadis dari Abad XVII - Sekarang)." Jurnal Studi Ilmuilmu Al-Quran dan Hadis 5, no. 1 (January 2004).

Zarif, Muhammad Mustaqim Mohd. “Jawah Hadis Scholarship in the Nineteenth Century: A Comparative Study of the Adaptions of Lubāb Al-Hadīth Composed by Nawawi of Banten (d. 1314/1897) and Wan 'Ali of Kelantan (d. 1331/1913)." Dissertation, University of Edinburgh, 2007. 